\title{
Colonization and diversification shape species-area relationships in three Macaronesian archipelagos
}

\author{
Jonathan P. Price ${ }^{1}$ (D) | Rüdiger Otto ${ }^{2} \mid$ Miguel Menezes de Sequeira $^{3}$ (D) \\ Christoph Kueffer $^{4}$ | Hanno Schaefer ${ }^{5}$ (D) | Juli Caujapé-Castells ${ }^{6}$ | \\ José María Fernández-Palacios ${ }^{2}$
}

\footnotetext{
${ }^{1}$ Department of Geography and Environmental Studies, University of Hawaii at Hilo, Hilo, Hawaii

${ }^{2}$ Island Ecology and Biogeography Research Group, Instituto Universitario de Enfermedades Tropicales y Salud Pública de Canarias (IUETSPC), Universidad de La Laguna, Tenerife, Canary Islands, Spain

${ }^{3}$ InBio, Research Network in Biodiversity and Evolutionary Biology, CIBIO-Azores, Madeira Botanical Group (GBM), Universidade da Madeira, Funchal, Portugal

${ }^{4}$ Institute of Integrative Biology, Swiss Federal Institute of Technology (ETH), Zurich, Switzerland

${ }^{5}$ Department of Ecology and Ecosystem Management, Technische Universitaet Muenchen, Freising, Germany

¿Jardín Botánico Canario "Viera y Clavijo”-Unidad Asociada al CSIC (Cabildo de Gran Canaria), Las Palmas de Gran Canaria, Spain
}

\section{Correspondence}

Jonathan P. Price, Department of Geography and Environmental Studies, University of Hawaii at Hilo, 200 West Kawili Street, Hilo, HI 96720.

Email: jpprice@hawaii.edu

Editor: Kostas Triantis

\section{ABSTRACT}

Aim: Species-area relationships (SARs) on oceanic archipelagos are shaped at least as much by speciation as by immigration-extinction dynamics. We examine three well-studied Atlantic archipelagos to quantify the relative contributions of colonization and diversification to individual and whole-archipelago floras.

Location: Three Macaronesian archipelagos: the Azores, Madeira and Canary Islands.

Methods: We assessed the floras of all three archipelagos in order to compare SARs and numbers of endemic species with respect to the physical characteristics of each archipelago (geological age, isolation, and environmental diversity). Utilizing a large number of available phylogenies, we partitioned each flora into putative colonist lineages. These were used to determine: (a) the number of original colonists of each archipelago, (b) degree of relatedness among these, and (c) the degree to which internal diversification contributes to species numbers for islands and archipelagos with different physical characteristics.

Results: Archipelagos varied in the parameters of the SARs in relation to their physical characteristics. The Canarian and Madeiran floras demonstrate remarkably similar SARs with $z$ values (slopes) near 0.3, while the Azorean flora exhibits fewer species per given area and a modest $z$ value of 0.15 . The Canarian and Madeiran endemic species are concentrated in a small number of diversifying lineages, whereas the Azorean endemics were mostly in anagenetic lineages (indicating minimal internal diversification). Lineages that do not diversify within a given archipelago significantly tend not to diversify in others, whereas diversifying lineages tend to 
have more species in the Canarian flora when compared with related lineages in the others.

Main conclusions: Although a strong independent effect of island area on species richness exists for the whole Macaronesian region, colonization and diversification are also influenced by geological age and environmental diversity of archipelagos, overriding characteristics of individual islands ("archipelago effect"). The "Azorean diversity enigma" likely results from a combination of geological youth, low environmental diversity and disproportionate human alteration.

\section{KEYWORDS}

Azores, biodiversity, Canary Islands, flora, Macaronesia, Madeira, phylogeny, species-area relationship

\section{1 | INTRODUCTION}

The unique, disharmonic biotas of oceanic islands can be attributed to a combination of infrequent sweepstakes dispersal, followed by in situ evolution and diversification (Carlquist, 1974). MacArthur and Wilson's $(1963,1967)$ classic equilibrium model, where immigrationextinction rates respond to variation in area and isolation, may not apply to oceanic archipelagos for several reasons. First, dispersal to oceanic islands often comes from highly disparate regions rather than a single mainland source area (Carlquist, 1974; Cowie \& Holland, 2006; Fosberg, 1948) such that the overall "pool" of potential colonists is difficult to characterize. For example, phylogenetic analyses have established the origins of Hawaiian taxa from North America (Baldwin \& Wagner, 2010 and citations therein), Australia and New Zealand (Harbaugh \& Baldwin, 2007; Quinn, Cravn, Heslewood, Brown, \& Gadek, 2003), and Asia (Yi, Miller, \& Wen, 2004). Second, oceanic islands often exhibit surprisingly high habitat diversity, such that habitat composition may supersede area in shaping the numbers of species, particularly endemics (Fernández-Palacios \& Andersson, 2000; Price, 2004). Finally, and most importantly, evolutionary processes respond to various characteristics of islands. Diversification rate has a positive relationship to area for single islands (Losos \& Schluter, 2000) and whole archipelagos (Price \& Wagner, 2011; Santos et al., 2010; Triantis, Economo, Guilhaumon, \& Ricklefs, 2015), however this is likely limited to those groups prone to large radiations. Unlike the immigration rate, diversification rate should increase with isolation on oceanic islands, since a lower degree of colonization would leave ample niche space available (Heaney, 2000; Lomolino, 2000). Given the time-scale of evolutionary processes, the number of speciation events (and, typically, single island endemics) relates to the geologic and climatic histories of islands (Otto et al., 2016; Price, 2004; Whittaker, Triantis, \& Ladle, 2008; Whittaker et al., 2007).

The Macaronesian region comprises five volcanic archipelagos (Azores, Madeira, Salvages, Canaries, and Cape Verde) located off the Iberian Peninsula and North Africa (Figure 1; Fernández-Palacios, 2011). However, due to the relatively incomplete state of taxonomic work and the small number of resolved phylogenies, we decided not to include the Cape Verdean flora in this study, limiting our analyses to the four northernmost archipelagos (European Macaronesia). We henceforth use "Madeira" for the archipelago and "Madeira Island" for its main island. Together, these archipelagos comprise 26 islands $>1 \mathrm{~km}^{2}$, with a total land area of c. $11,000 \mathrm{~km}^{2}: 9$ islands in the Azores, 3 in Madeira, and 12 in the Canaries, respectively (here we include Selvagem Grande with the Canaries due to its comparative proximity) (Table 1).

All islands emerged from the sea as volcanoes, with Selvagem Grande being the oldest at 29 Myr (Fernández-Palacios, 2011) and Pico (Azores) the youngest at 0.25 Myr (França, Cruz, Nunes, \& Forjaz, 2005). Volcanic activity has persisted to the present in the Azores and the Canaries (Fernández-Palacios \& Dias, 2001) and until as recently as 6-7 ka in Madeira (Geldmacher, van den Bogaard, Hoernle, \& Schmincke, 2000). The Azorean archipelago is composed of nine volcanic islands. Santa Maria, the oldest island at $6 \mathrm{Myr}$, experienced subsidence up to $3.5 \mathrm{Myr}$, followed by uplift extending to the present day (Ramalho et al., 2017), and Pico, its youngest, is

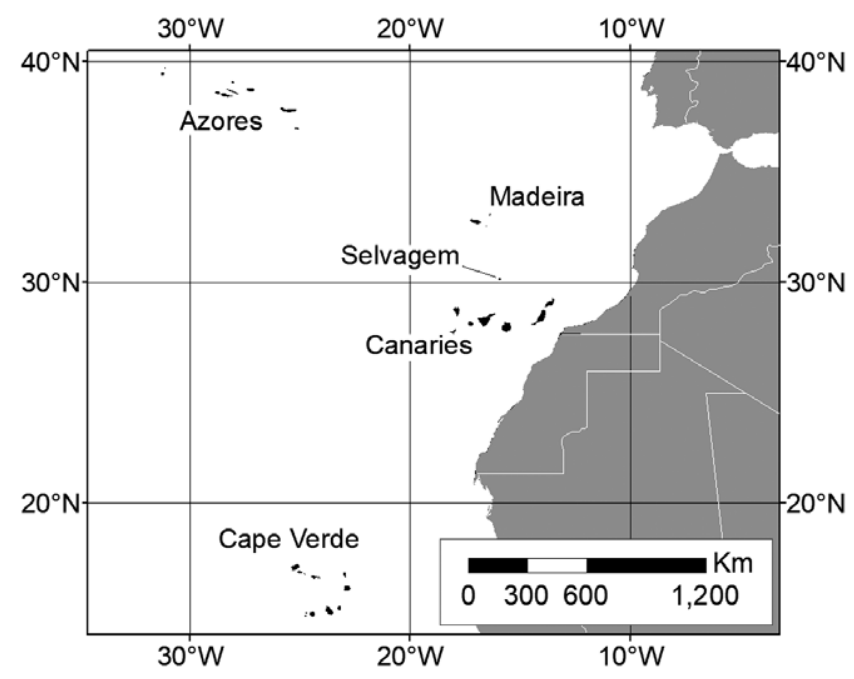

FIGURE 1 Map of the Macaronesian Region. The Cape Verde archipelago was not included in this study 
TAB LE 1 Geographic and geological parameters of the European Macaronesian Islands. Source: Fernández-Palacios (2011). In this analysis, the Selvagens Islands, although politically belonging to Madeira, were included within the Canaries due to their comparative proximity

\begin{tabular}{llll} 
& Azores & Madeira & Canaries \\
\hline $\mathrm{N}^{\circ}$ islands $>1 \mathrm{~km}^{2}$ & 9 & 5 & 12 \\
\hline Area $\left(\mathrm{km}^{2}\right)$ & 2,764 & 815 & 7,445 \\
\hline Maximum elevation $(\mathrm{m})$ & 2,351 (Pico) & 1,862 (Madeira Island) & 3,718 (Tenerife) \\
\hline Continental isolation (km) & 1,369 (São Miguel-Lisbon) & 630 (Porto Santo - North Africa) & 96 (Fuerteventura - North Africa) \\
\hline Age of the oldest emerged island (Myr) & 6 (Santa Maria) & 14 (Porto Santo) & 29 (Selvagem Grande) \\
\hline Last subaereal eruption & 1957 (Faial) & $6-7$ kyr BP (Madeira Island) & 1971 (La Palma) \\
\hline North latitude $\left(^{\circ}\right)$ & $37-40$ & 33 & $27-29$ \\
\hline
\end{tabular}

just 0.25 Myr (França et al., 2005; Sibrant et al., 2015). Volcanic activity (Forjaz, 2002) and glacioeustatic sea level changes (Rijsdijk et al., 2014) joined islands together at different times. Porto Santo (14 Myr) is the oldest island of Madeira, whereas Madeira Island, with most of the archipelago's area, is younger (6 Myr; Geldmacher et al., 2000). Despite the age of the oldest islands (21 Myr for Fuerteventura and 29 Myr for Selvagem Grande), the Canaries have experienced recent volcanism across most islands. Low sea level during glacial periods both joined islands together and reduced distance to the African mainland (García-Talavera, 1999).

However, Madeira and the Canaries share an essentially Mediterranean climate (mild, humid winters and warm, dry summers), while an oceanic temperate climate (cool, wet) prevails throughout the year in the Azores (de Nicolás, Fernández-Palacios, Ferrer, \& Nieto, 1989). Madeira Island's tall landmass results in a rainshadow that produces a range of habitats. With three islands taller than Madeira Island, culminating at the summit of El Teide $(3,718 \mathrm{~m})$, the Canaries exhibit even greater ecosystem diversity. The comparatively low altitude of the Azores (with the exception of Pico's peak, 2,351 m), has given rise to a more modest range of habitats.

The Azorean flora is comparatively poor in species, with modest endemicity (Silva, Moura, Schaefer, Rumsey, \& Dias, 2010). This relatively low degree of endemism despite considerable isolation represents a pattern dubbed "the Azores diversity enigma" (Carine \& Schaefer, 2010). Recent debate centres on to whether this pattern results from geological youth and homogeneous habitats (Triantis, Hortal, et al., 2012) or whether diversity and endemism may be cryptic and under reported (Schaefer et al., 2011). The Madeiran flora is more diverse (Jardim \& Menezes Sequeira, 2008), and the Canarian flora even richer (Acebes et al., 2010). Floristic patterns are nonetheless obscured by a long history of human alteration. With human occupancy dating to around 2,500 BP, the Canaries have the longest history of anthropogenic change (de Nascimento, Willis, Fernández-Palacios, Criado, \& Whittaker, 2009), while the other two archipelagos were settled starting in the 15th century (Vieira, 2001). The Azores have been almost completely deforested, whereas the complex topography of the Canaries and Madeira has limited conversion of natural vegetation to pasture and agriculture. We can therefore assume that the floras of these archipelagos, particularly the Azores, represent altered patterns of diversity and endemicity.
Previous studies in the Macaronesian region have related diversity and endemism to island characteristics (area, geologic age, climate and degree of isolation) (de Nicolás et al., 1989; FernándezPalacios \& Andersson, 2000). In this study, we seek to explicitly evaluate how these characteristics influence two key biogeographical processes, colonization and diversification, in order to understand their relative contributions to overall species numbers, and by extension species-area relationships. We distinguish internal speciation that adds to the total species number (henceforth termed diversification) from speciation that only separates a single endemic species from a colonist ancestor (henceforth termed anagenesis) following Stuessy et al. (2006); the true number of speciation events is offset by an unknown number of extinction events, and therefore this definition refers to net diversification. At present most phylogenies (the key tool in evaluating these processes) have only been resolved at the scale of whole archipelagos, and we therefore explicitly compare these processes at that scale, with additional consideration of species-area relationships (SARs).

We should expect colonization to favour archipelagos that are larger, older, environmentally more diverse and closer to mainland sources (Carlquist, 1974; MacArthur \& Wilson, 1963, 1967). The Canarian flora should therefore have assembled from a greater number of colonists compared with the other two. Despite being larger than Madeira, the Azores are considerably more isolated, geologically younger and exhibit more modest habitat diversity; we therefore expect Madeira to have experienced more colonization than the Azores. By comparison, diversification should be most pronounced on archipelagos that are larger (Losos \& Schluter, 2000; Price \& Wagner, 2011), older (Price, 2004; Whittaker et al., 2007, 2008), environmentally more diverse and more remote (Heaney, 2000; Lomolino, 2000). Despite their apparent lack of isolation, the Canaries are actually somewhat removed from the source area for much of the flora (the Mediterranean region). Additionally, the area, geologic age and range of available habitats are likely to promote considerable diversification, especially in the westernmost islands, which have been environmentally more complex during the last few million years (Caujapé-Castells et al., 2017). Madeira is comparable to the Canaries in many ways, but being a smaller archipelago, we expect less diversification. On the one hand, the Azores' isolation should enhance diversification, however, this effect may be tempered by 
their geological youth and comparatively lower climatic complexity; by explicitly examining the relative roles of colonization and diversification, we have an opportunity to evaluate the "Azores diversity enigma" in the context of key processes across archipelagos (Carine \& Schaefer, 2010; Triantis, Hortal, et al., 2012).

\section{2 | MATERIALS AND METHODS}

\section{1 | Species data}

We collated species occurrence data for all three archipelagos using the latest versions of the vascular plant species checklist for the Azorean (Silva et al., 2010), Madeiran (Jardim \& Menezes Sequeira, 2008) and Canarian (Acebes et al., 2010) archipelagos. These provided both presence data for individual islands, and chorological status at the level of archipelago: (a) endemic genus, (b) endemic species, (c) native non-endemic (NNE) species. The Canaries checklist does not include data for the islets north of Fuerteventura (Lobos) and Lanzarote (Alegranza, Montaña Clara and La Graciosa), however we compiled additional available information for these (Kunkel, 1970, 1971; Marrero, 1991) as summarized in Fernández-Palacios, Negrín, Fernández Lugo, Arévalo, and de Nascimento (in press).

The native status of many species remains uncertain due to a long history of human occupancy (especially the Canaries, Rando et al., 1999), frequent travel from the nearby Mediterranean region, and the suitability of Macaronesian habitats to species of Mediterranean origin. For NNE species, we therefore only considered those species most likely to naturally occur according to the databases consulted (nativa seguro [native with certainty]) and excluding species that are limited to highly disturbed habitats. Using this treatment, species numbers for island and archipelagos are somewhat smaller than reported elsewhere (Acebes et al., 2010; Jardim \& Menezes Sequeira, 2008; Silva et al., 2010).

\section{2 | Colonist Lineages}

Within each archipelago, we assigned each species to a putative colonist lineage. In numerous cases, these are well-supported by phylogenetic studies that highlight relationships among endemic species and related taxa from source areas (Domínguez-Lozano, Price, Otto, \& Fernández-Palacios, 2010; Reyes-Betancort, Santos-Guerra, Guma, Humphries, \& Carine, 2008). Phylogenetic analyses include many of the largest lineages in the Macaronesia, accounting for large proportions of endemic species in the Canaries and Madeira in particular (Table 2). Overall, 12 lineages contain $>10$ species in at least one archipelago.

With few exceptions, we consider NNE species to represent single (or recurrent) colonization events to Macaronesia without subsequent speciation. In cases where NNE species have closely related endemic species, phylogenetic studies are often available. For the Canaries we generally followed the treatment by Domínguez-Lozano et al. (2010), with some exceptions where new phylogenetic data were available.
In order to assess the degree to which source taxa are similar among archipelagos, we grouped lineages in different archipelagos where they represent closely related taxa. For example, the Aeonium alliance constitutes a largely Macaronesian clade (Mort, Soltis, Soltis, Francisco-Ortega, \& Santos-Guerra, 2002), and thus representative taxa on each archipelago are closely related even where species are endemic to different archipelagos. NNE species that are shared between archipelagos also clearly represent closely related colonizations. In other cases, multiple archipelagos will contain members of a given genus, however the taxa are closely related whether there has been colonization of one archipelago followed by dispersal to another or separate colonization events for multiple archipelagos. In either scenario, two archipelagos can be said to "share" a lineage in the sense that they have taxa whose colonist ancestors were closely related, if not one and the same.

\subsection{Contributions of colonization versus diversification}

We assessed the relative contributions of colonization and internal diversification on each archipelago's flora following Price and Wagner (2011). In some cases, a species arrived repeatedly (as is the case with widespread NNE species), however only the initial arrival is considered a colonization in the strict sense. The number of colonist lineages in a given archipelago represents the number of species contributed to a given flora by net colonization (accounting for the possibility that some colonist lineages may have gone extinct). The number of species subsequently added by net internal diversification equals the total number of species minus the number of colonization events. In this manner, we compared the numbers of species contributed by each additive process to the whole archipelago area in order to assess the degree to which area contributes to each.

\subsection{Key lineages}

In order to determine the proportional contribution of diverse lineages to net diversification, we characterized the distribution of lineage size within each archipelago and identified the largest lineages (Table 2). Due to the possibility that a given diversifying lineage failed to colonize one or more archipelagos, we considered the "lineage composition" of each archipelago and the degree to which they share related lineages. We determined the overall number of species that are shared among archipelagos and unique to individual archipelagos, as well as the number of related lineages shared among them.

A given archipelago may have been colonized by diversifying lineages with no relatives in other archipelagos. To test this, we produced contingency tables of the numbers of single versus multispecies lineages (Table 3) and numbers of lineages that have close relatives versus no close relatives in at least one other archipelago (Table 4). We used a chi-squared test to assess whether there is a disproportionately high number of lineages that have diversified, but which have no close relatives in the other archipelagos. In such 
TAB LE 2 Prominent radiations of Macaronesian plants. There are 12 lineages that contain more than 12 species in Macaronesia. In some cases, the original colonist diversified into many species constituting multiple genera. Together, these diversifying groups comprise a large portion of the endemic species diversity in these archipelagos

\begin{tabular}{llllll} 
Lineage & Family & Azores & Madeira & Canaries & Reference \\
\hline Aeonium alliance & Crassulaceae & 1 & 5 & 52 & Mort et al. (2002) \\
\hline Sonchus alliance & Asteraceae & 0 & 4 & 30 & Kim et al. (1996) \\
\hline Echium & Boraginaceae & 0 & 2 & 23 & Böhle, Hilger, and Martin (1996) \\
\hline Sideritis & Lamiaceae & 0 & 1 & 24 & Barber, Francisco-Ortega, Santos-Guerra, Marrero, and Jansen (2000) \\
\hline Argyranthemum & Asteraceae & 0 & 3 & 20 & Francisco-Ortega, Jansen, and Santos-Guerra (1996) \\
\hline Lotus & Fabaceae & 1 & 5 & 19 & Allan, Francisco-Ortega, Santos-Guerra, Boerner, and Zimmer (2004) \\
\hline Limonium & Plumbaginaceae & 1 & 0 & 16 & Lledó, Crespo, Fay, and Chase (2005) \\
\hline Micromeria & Lamiaceae & 0 & 1 & 15 & Meimberg et al. (2006) \\
\hline Cheirolophus & Asteraceae & 0 & 1 & 16 & Susanna, Garnatje, and García-Jacas (1999) \\
\hline Crambe & Brassicaceae & 0 & 1 & 13 & Francisco-Ortega et al. (2002) \\
\hline Pericallis & Asteraceae & 1 & 1 & 12 & Swenson and Manns (2003) \\
\hline Helianthemum & Cistaceae & 0 & 0 & 12 & Reyes-Betancort et al. (2008) \\
\hline Total & & 4 & 27 & 250 & \\
\hline \% of endemic species & & 4 & 12 & 46 & \\
\hline \% of native flora & & 4 & 7 & 28 & \\
\hline
\end{tabular}

TABLE 3 Comparison of lineages with and without close relatives

\begin{tabular}{lll}
\hline A & Canaries single & Canaries multi \\
\hline Relatives & 163 & $53^{* * *}$ \\
\hline No relatives & 230 & 33 \\
\hline B & Madeira Single & Madeira Multi \\
\hline Relatives & 223 & 23 \\
\hline No Relatives & 61 & 4 \\
\hline C & Azores Single & Azores Multi \\
\hline Relatives & 91 & 5 \\
\hline No Relatives & 50 & 5 \\
\hline
\end{tabular}

Note.. Each contingency table shows, for a given archipelago, the numbers of lineages with one versus multiple species and that have relatives versus no relatives: (A) Canaries $\left(\chi^{2}=11.53 ; p<0.001\right) * * *$, (B) Madeira $\left(\chi^{2}=0.660 ; n s\right),(C)$ Azores $\left(\chi^{2}=0.685 ; n s\right)$.

a case, higher diversity would appear to be driven by the chance colonization of key lineages that tend toward diversification.

\section{5 | Generalized linear models}

In order to test our hypotheses about the relative influences on colonization and diversification, we applied both generalized linear models (GLM, McCullagh \& Nelder, 2002) and generalized linear mixed-effect models (GLMM, Bates, Maechler, Bolker, \& Walker, 2014), including all islands of the three archipelagos $(n=23)$ and using a Poisson error distribution and log link function for all richness groups (Quinn \& Keough, 2002). Beside island area, island geological age (as single and quadratic term, following the GDM approach (Borregaard et al., 2017; Whittaker et al., 2008), island altitude, island distance to the Iberian Peninsula, island environmental diversity, archipelago age effect and habitat loss were used as fixed
TABLE 4 Comparison of related lineages between archipelagos

\begin{tabular}{lcl}
\hline A & Canaries single & Canaries multi \\
\hline Madeira single & 154 & 34 \\
\hline Madeira multi & 4 & $18^{* * *}$ \\
\hline B & Canaries single & Canaries multi \\
\hline Azores single & 48 & 8 \\
\hline Azores multi & 3 & 1 \\
\hline C & Madeira single & Madeira multi \\
\hline Azores single & 78 & 8 \\
\hline Azores multi & 3 & 1 \\
\hline
\end{tabular}

Note.. Each contingency table shows, for each pairwise comparison, the numbers of related lineages with one vs. multiple species in each given archipelago. (A) Canarian-Madeiran comparison $\left(\chi^{2}=42.90 ; p<0.001\right)$ ***; (B) Canarian Azorean comparison $\left(\chi^{2}=0.036\right.$; ns) and (C) MadeiranAzorean comparison $\left(\chi^{2}=1.046\right.$; ns).

factors. The archipelago was introduced as a random factor in GLMMs to count for the spatial structure in the data and the effect of pseudo-replication. Island environmental diversity was defined by two parameters assessed for each island as a whole: (a) the quotient between maximum and minimum mean annual temperature and (b) the quotient between maximum and minimum mean annual precipitation on each island (Mestre Barceló et al., 2012). Archipelago age effect was measured as the difference between island age and the age of the oldest island in the archipelago, representing the time available for diversification within the archipelago prior to the emergence of a given island. Habitat loss was defined as the percentage of natural habitats displaced by human activity (del Arco et al., 2006; Menezes de Sequeira, unpubl. data; Triantis et al., 2010). Selvagem Island was not included in the multiple regression analysis (additional analyses which included Selvagem exhibited very little difference). 
Using a multimodel setting, we examined the Akaike information criterion corrected for small sample size ( $\mathrm{AIC}_{\mathrm{c}}$ ) of all combinations of models, including the seven standardized explanatory variables in order to check relative importance of predictors and to select the best model for each species group with the lowest $\mathrm{AlC}_{\mathrm{c}}$ (Burnham \& Anderson, 2002). Variation accounted for by the best GLMM was quantified using the pseudo- $R^{2}$ value. Finally, we plotted the partial residuals for island area of the best models for each species group which show the relationship between island area and the residuals from a model without island area but including the other significant explanatory variables.

All statistical analyses were performed in an $\mathrm{R}$ environment (3.4.2, R Development Core Team, 2017) using the packages 'Ime4' (1.1-17) for GLMM analyses, 'AICcmodavag' (2.0-4) for best model selection and 'MuMIn' (1.40.0) and 'BaylorEdPsych' (0.5) for pseudo- $R$-squared.

\section{3 | RESULTS}

\section{1 | Species-area relationships}

When applying the traditional SAR approach, all three archipelagos exhibited significant individual SARs, with notable differences (Figure 2). The Canaries and Madeira have very similar z-values (slope) around 0.30 and comparable $c$-values (intercepts). The Azores archipelago exhibits a much more modest $z$-value of 0.14 . Madeira Island is almost identical to La Palma in both species number and area.

Ignoring diversification and focussing on the lineage-area relationship (LAR) in the three archipelagos, the differences among archipelagos are less pronounced, but still important. The larger islands of the Canaries and Madeira contain more than twice the number of lineages as Azorean Islands of comparable area. Z-values for Madeira and the Canarias are very similar, but lower for the Azores. When comparing SARs for species originated from diversification, the Canaries showed the highest $z$-values $(0.66)$, followed by Madeira (0.45) and the Azores (0.31).

In the GLMM approach, the island area had the greatest explanatory power of the seven selected predictor variables in explaining richness in all species groups (Table 5). However, geological age of the island and the archipelago age effect were also important predictors. Island age always showed a hump-shaped relationship with species richness, while the archipelago effect had an overall positive effect on richness. The island's environmental diversity was positively correlated with the total number of native species, whereas the distance to the Iberian Peninsula showed a positive influence on all species groups. GLM models revealed similar results but with stronger influence of island age and archipelago age probably due to the lack of the random factor that accounts for the unexplained variance between archipelagos.

Habitat loss and island altitude were not selected as significant variables in any model. The predictors selected by the best models were all highly significant and explained a high proportion of the variation, indicated by the pseudo- $R^{2}$ values. Partial residuals plots of best models showed unique Macaronesian SARs with very good fit $\left(R^{2} \geq 0.88, n=23\right)$. This suggests a strong independent effect of island area on species richness for the whole Macaronesian region when controlling for other significant explanatory variables.

\subsection{Distributions of species and lineages among archipelagos}

Of the total of 1,182 native vascular plant species in European Macaronesia (Figure 3a), 972 (82\%) are exclusive to one archipelago, 178 (15\%) are shared among two archipelagos and only $32(3 \%)$ are represented in all three (Figure 3a). A large majority of Canarian species (721 of 900 , or $80 \%$ ) are not shared with any other archipelago. Madeira shares a majority of their species with other archipelagos (207 of 361 , or $57 \%$ ), mostly with the Canaries. The Azores also share a majority of their species with other archipelagos (97 out of 153 , or $63 \%$ ), mostly with Madeira. The overall rate of within-archipelago endemicity is the highest for the Canaries (60\%), with the Azores (32\%) slightly exceeding Madeira (30\%).

As defined here, there are 635 lineages present in Macaronesia (Figure 3b). The Canaries have the highest number of lineages (479), followed by Madeira (311) and finally, the Azores (151). The Canaries are roughly split between lineages that are shared with the others (216) and those that are not (263); much of the unshared portion is comprised of NNE species shared with Africa and not found in the other archipelagos. Madeira shares many more lineages (246) than not (65). Finally, the Azores share two-thirds of their lineages (96). Overall, this points to a pattern of similar composition among lineages (i.e. archipelagos are colonized by related taxa).

\section{3 | Multispecies versus related colonist lineages}

For the Canaries (Table 3a), lineages with multiple species are more likely to have relatives in other archipelagos $\left(x^{2}=11.53 ; p<0.001\right)$. In Madeira and Azores (Tables 4b,c, respectively), there is no significant relationship between having multiple species and having relatives in another archipelago.

Pairwise comparisons involving related lineages differ in terms of which lineages undergo diversification in each archipelago (Table 4). In all archipelagos, most lineages overall contain a single species. Overwhelmingly, related lineages that had a single species in a given archipelago had a single species in the other. Lineages with more than one species in Madeira disproportionately contain multiple species in the Canaries (Table 4a), likewise for single species lineages $\left(\chi^{2}=42.90\right.$; $p<0.001$ ). However, for the rest of possible comparisons (AzoresMadeira and Azores-Canaries) there is no significant trend at all.

\section{4 | DISCUSSION}

\subsection{Species number as a function of colonization and diversification}

The species-area relationship for the Canaries reported here differs from that reported by Fernández-Palacios and Andersson (2000), 
FIGURE 2 Species-area relationships (SARs) for (a) total native richness, (b) lineages and (c) species originated by diversification. SARs are considered separately for each archipelago (Canaries, Madeira and Azores) and together for the whole Macaronesian Region using a multiple regression approach. Partial residuals plots of multiple generalized linear models show the relationship between island area and the residuals from a model without island area but including the other selected significant explanatory variables (island age, archipelago age effect, island environmental diversity, island distance to the Iberian Peninsula, see results Table 5) highlighting the independent effect of island area on species richness
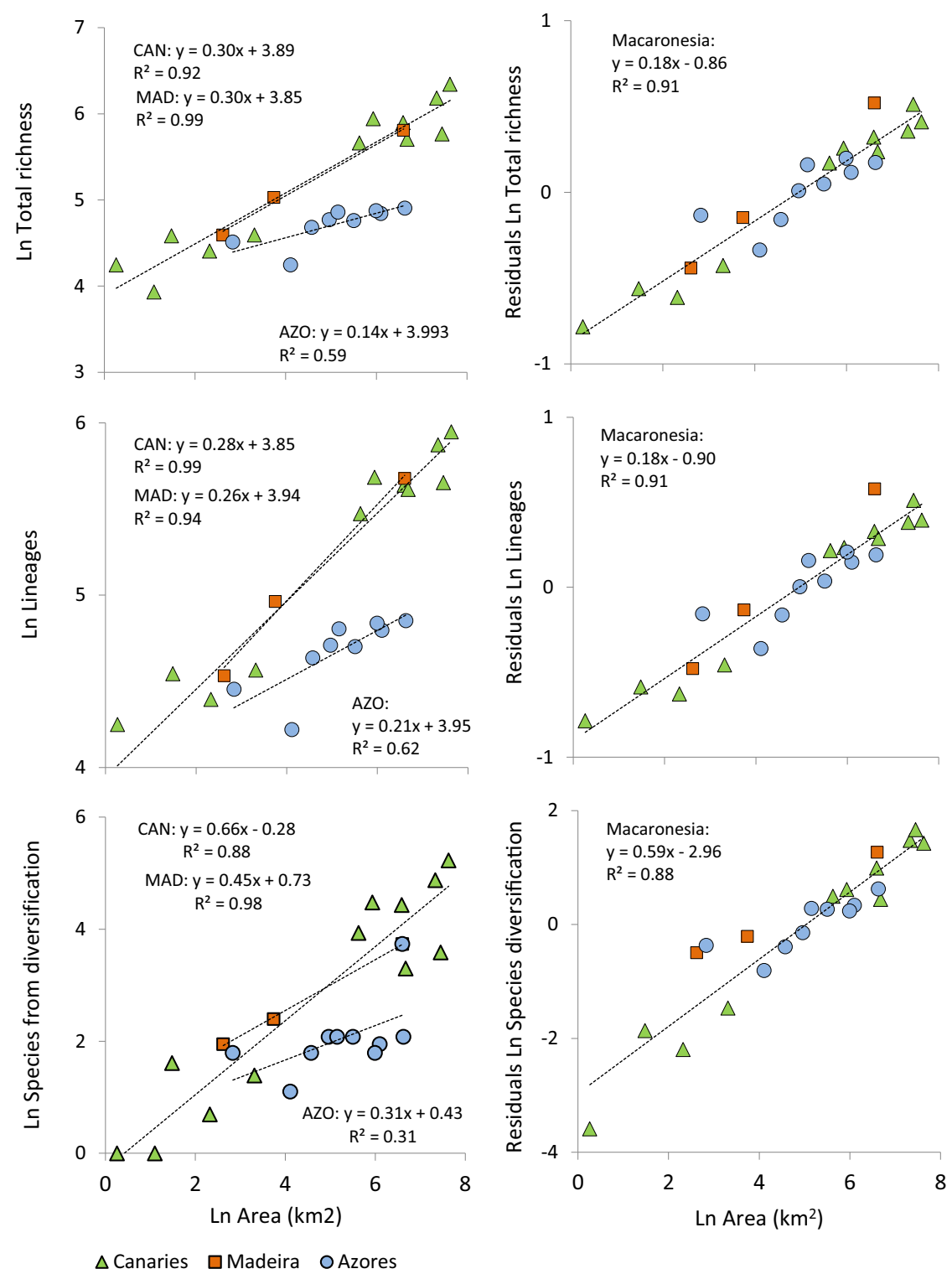

$\Delta$ Canaries $\square$ Madeira OAzores although they only included the Eastern Canaries in order to control for habitat variation. Here, we report SARs that are broadly comparable between the Canaries and Madeira (Figure 2a), with z-values (both $\sim 0.30$ ) only slightly lower than those found for the floras of three Pacific archipelagos (Price \& Wagner, 2011), but nonetheless within the expected range for oceanic archipelagos (Rosenzweig, 1995). The anomalously low z-value for the Azores ( 0.14; Figure 2a) may stem from various causes. Remote archipelagos like the Azores contain large numbers of so-called "waif" species that readily disperse long distances (Carlquist, 1974); biotas consisting of such highly dispersable taxa can exhibit very low z-values (MacArthur \& Wilson, 1967; Triantis, Guilhaumon, \& Whittaker, 2012). Nonetheless, the three Pacific archipelagos examined by Price and Wagner (2011) are considerably more isolated than the Azores yet exhibit more standard z-values.

Parsing SARs into the relative contributions of colonization and diversification provides a better lens for deconstructing the constituent processes underlying them (Figure $2 \mathrm{c}, \mathrm{d}$ ). The Canaries and
Madeira exhibit LARs (essentially representing the colonization component) with z-values slightly lower than those for SARs, and strongly similar to each other. However, the Canaries support a larger number of species contributed by diversification per area than Madeira (steeper slope), and with the Azores far below the other two. Diversification in this sense means that speciation outpaces extinction, resulting in a net addition of species; however it remains unclear whether the higher net diversification in the larger archipelago is driven by a higher speciation rate or a lower extinction rate. Either way, this supports the notion that larger areas promote diversification (Kisel \& Barraclough, 2010; Losos \& Schluter, 2000).

Considering the nature of diversification within these archipelagos, three hypotheses emerge to explain why there is generally more diversification in the Canaries compared with the other two. First, we consider the possibility that the Canaries have received lineages generally more favourable to diversification. Lineages colonizing a given archipelago are likely to have a related lineage in one of the other two, although the Canaries have many lineages without close 
TAB LE 5 Results of generalized linear models (GLM) and generalized linear mixed-effects models (GLMM) for total species richness, the number of lineages and the number of species added through cladogenesis per island as dependent variables and island area, island age (single and quadratic term), archipelago age effect, measured as the difference between island age and the age of the oldest island in the archipelago, environmental diversity of the island measured as quotient between maximum and minimum mean annual precipitation, and distance to Iberian peninsula as possible predictors. Intercept, coefficient estimates and standard errors, $z$-value from Wald-statistics and pseudo $R^{2}$ are shown

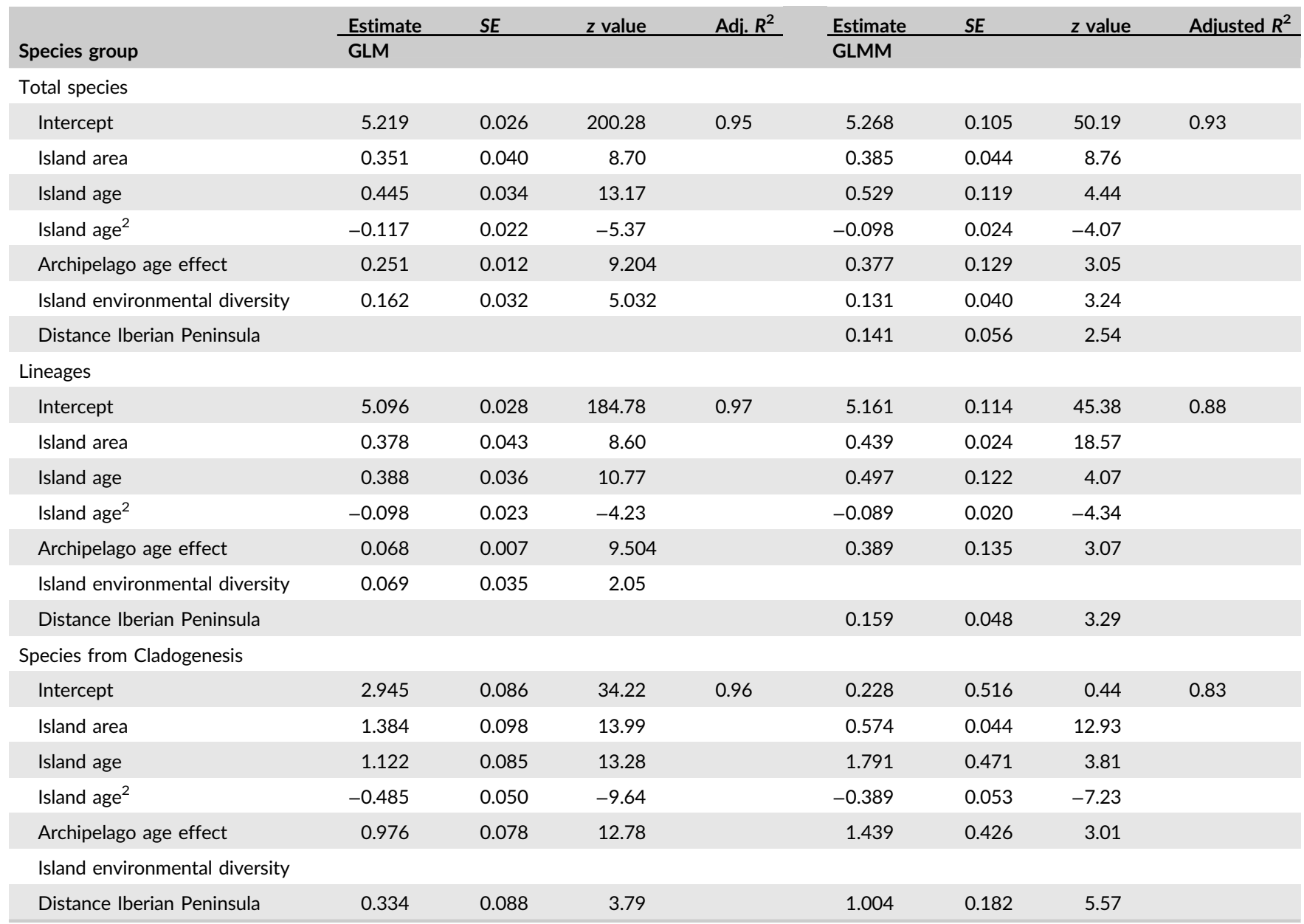

relatives in either of the other two (Figure 3b). This is a somewhat greater degree of relatedness among archipelagos than was found among the three Pacific archipelagos (Price \& Wagner, 2011), which may be expected given the much greater isolation among the latter. Nonetheless, our analyses do not support greater diversification in the Canaries due to the chance colonization of diversifying lineages. For Madeira and the Azores, there was no relationship between having multiple species and having related lineages; for the Canaries, lineages with multiple species were actually positively associated with having related lineages (Table 3 ). Contrastingly, the Azores, have only 10 multispecies lineages, five of which have no related lineages in the other archipelagos.

A second way of viewing diversification is in terms of how related lineages behave in different archipelagos. Lineages diversifying in the Canaries were likely to diversify in Madeira, but not the Azores (Table 4). Although there are radiating lineages exclusive to Madeira (Musschia, Sinapidedron, etc.) or to the Canaries (Helianthemum, Polycarpaea, etc.), the more diverse lineages are shared between the two (Aeonium alliance, Sonchus alliance, Echium, Argyranthemum, etc.). In contrast, there is just a single Azorean species in each of the otherwise diverse Aeonium alliance, Limonium, Lotus and Pericallis clades.

Finally, the relationship between the degree of diversification in the Canaries versus Madeira greatly reflects the pattern seen in the Pacific: where multispecies lineages are related, the Canaries had an average of 2.6 times the number of species of the related lineage in Madeira.

\subsection{The archipelago effect (top-down effect of age and area)}

Diversification accounts for 421 species in the Canaries (47\% of the flora) and 50 species in Madeira (14\% of the flora). These contributions from diversification are more modest than in the Pacific archipelagos (for example, 743 species or $74 \%$ of the Hawaiian flora), but nonetheless point to a strong effect, particularly in the Canaries. 
(a)

Total Species

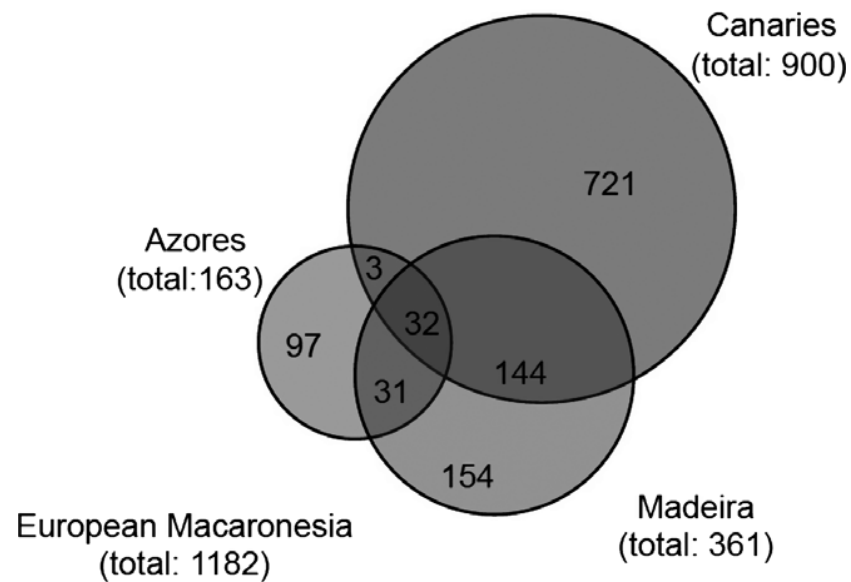

(total: 1182)

(b)

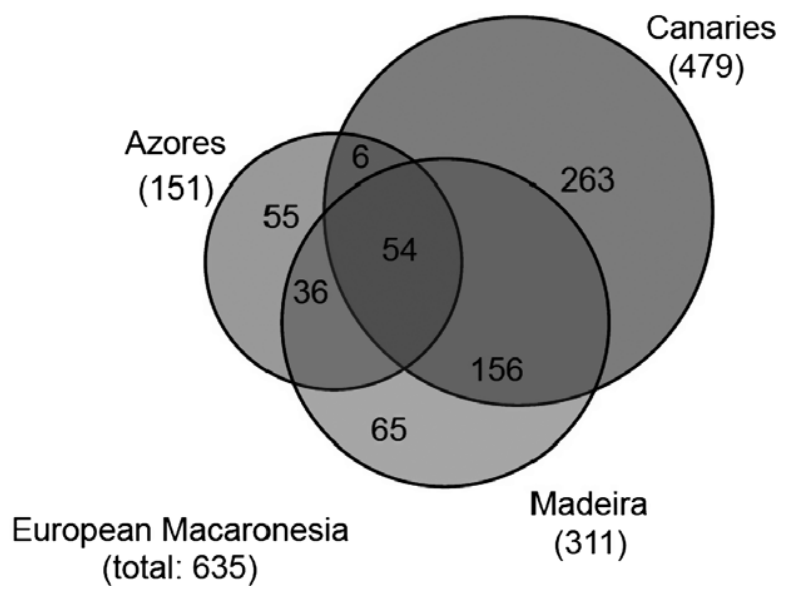

FIGURE 3 Total species numbers distribution among Macaronesian archipelagos. Numbers of (a) species and (b) lineages are conceptualized by overlapping circles, indicating how many are unique or shared with other archipelagos. In parentheses total number of species and lineages are given

Again, results of our multiple regression analysis support the idea that, together with area, geological age promotes diversification. Interestingly, not only island age but also the age of the archipelago is related to the number of species present on an island (Triantis, Whittaker, Fernández-Palacios, \& Geist, 2016). Hence, in addition to the age of a specific island, we propose a top-down "archipelago effect" whereby diversification within the archipelago as a whole, largely moderated by its age and area, influences individual islands. Old, large islands harbouring a large pool of diversified lineages promote diversification on younger islands within the Canary archipelago; the Azores lack such a species pool feeding young islands. Moreover, there is no evidence for sunken palaeo-islands in the Azores region, whereas both Madeira and the Canaries are surrounded by a range of eroded islands that might increase the available time for colonization considerably (Fernández-Palacios et al.,
TABLE 6 Comparison of endemic species in radiating taxa in La Palma (Canaries) and Madeira. Numbers of SIE species are shown in parentheses

\begin{tabular}{lcc|}
\hline Lineage & La Palma & Madeira Island \\
\hline Aeonium alliance & $20(5)$ & $4(1)$ \\
\hline Sonchus alliance & $7(2)$ & $3(1)$ \\
\hline Sideritis & $2(1)$ & $1(0)$ \\
\hline Echium & $8(5)$ & $2(0)$ \\
\hline Argyranthemum & $4(1)$ & $3(2)$ \\
\hline Lotus clade & $4(2)$ & $4(0)$ \\
\hline Micromeria & $2(1)$ & $1(0)$ \\
\hline Cheirolophus & $5(4)$ & $1(0)$ \\
\hline Crambe & $3(1)$ & $1(0)$ \\
\hline Pericallis & $2(1)$ & $1(0)$ \\
\hline Total & $57(23)$ & $21(4)$ \\
\hline
\end{tabular}

2011). This fits into the idea that the two most important factors driving diversification are environmental opportunity on new islands and the pool of already diversified lineages in the source region, whether archipelago or continent (Takayama, Crawford, López-Sepúlveda, Greimler, \& Stuessy, 2018).

This effect can be illustrated by comparing the islands of La Palma and Madeira. These two islands are comparable in area (729 vs. $737 \mathrm{~km}^{2}$ ) and the range of habitats present, although La Palma is somewhat taller $(2,425$ vs. $1,850 \mathrm{~m})$. They also differ considerably in age: Madeira Island formed $6 \mathrm{Ma}$ and La Palma just 1.8 Ma. However, the most important difference may be the fact that La Palma belongs to an archipelago (the Canaries) having several larger and older islands whereas Madeira Island is the only large, high island of its archipelago. First, despite being younger than Madeira Island, La Palma has more species overall (364 vs. 333). La Palma supports somewhat fewer colonist lineages than Madeira Island (281 vs. 292), but more species per lineage (1.3 vs. 1.14), suggesting that its flora has been enhanced by diversification occurring on older Canaries.

Looking more closely at individual diversifying lineages, related lineages almost universally contain more species on La Palma than Madeira Island. To be clear, this does not mean that there is greater diversification within La Palma, but rather that La Palma has been colonized from other Canary Islands multiple times after diversification has occurred in those (Caujapé-Castells et al., 2017; Curto, Puppo, Kratschmer, \& Meimberg, 2017). For example, La Palma includes twenty species representing all four genera (corresponding to major clades) within the large Aeonium alliance, whereas Madeira Island only has four species representing two genera. Similarly, in the Sonchus alliance, La Palma has seven species representing three out of the six genera in the Macaronesian clade (including Lactucosonchus, which is endemic to the island), whereas Madeira Island only has three species in the genus Sonchus (Table 6). The adaptive nature of the radiations means that functional diversity (formed by basal splits separating genera with distinct morphologies) readily 
TABLE 7 Comparison of species number among lineages undergoing diversification in the Azores. With the exception of Tolpis, herbaceous genera that radiate in Azores are either absent in Madeira and the Canaries, or if present, do not radiate

\begin{tabular}{lllll} 
Lineage & Family & Azores & Madeira & Canaries \\
\hline Leontodon & Asteraceae & 3 & 0 & 0 \\
Platanthera & Orchidaceae & 3 & 0 & 0 \\
\hline Tolpis & Asteraceae & 2 & 2 & 7 \\
\hline Festuca & Poaceae & 2 & 1 & 1 \\
\hline Holcus & Poaceae & 2 & 1 & 1 \\
\hline Ammi & Apiaceae & 2 & 0 & 1 \\
\hline Agrostis & Poaceae & 2 & 0 & 0 \\
Euphrasia & Orobanchaceae & 2 & 0 & 0 \\
Myosotis & Boraginaceae & 2 & 0 & 0 \\
\hline
\end{tabular}

spreads between islands within the more complex Canaries, followed by additional allopatric speciation in the more distal branches (Kim, Francisco-Ortega, \& Santos-Guerra, 1996; Mort et al., 2002).

\section{3 | Revisiting the "Azores Biodiversity Enigma"}

Our analysis underscores a comparatively homogeneous flora in the Azores, with little difference among islands of different area, as evidenced by the very low z-value. Of course, the low numbers of species overall (and contributed by colonization and diversification) likely also reflect more severe habitat loss in the Azores. While we did explore the percentage habitat loss for each island as a variable, it was not selected as a significant predictor.

The modest altitudes among the Azorean islands (all less than $1,200 \mathrm{~m}$, with the exception of the very young Pico at 2,350 m) have resulted in less habitat heterogeneity when compared with the other archipelagos, restricting possibilities for colonization and diversification. As a result, radiating lineages shared by Madeira and the Canaries either do not naturally occur in the Azores (Argyranthemum, Echium, Sonchus clade) or if present (Aeonium clade, Pericallis), they simply have not diversified there. All of the diversifying lineages that do occur in the Azores (Table 7) are herbaceous, a pattern at odds with the rest of Macaronesia, where nearly all of the most diverse lineages are woody. Considering that only half of the Azorean multispecies lineages occur in the other archipelagos, all but Tolpis have failed to diversify outside of the Azores. Therefore, diversification within the Azorean archipelago, despite being less frequent than in the other two, is nonetheless distinct (Figure 4). The reason for this contrasting pattern may partly derive from the relationship between climate and the continental species pool feeding this archipelago. The Azorean climate (wet throughout the year) differs from that of Madeira and the Canaries, which have more Mediterranean type climates (Fernández-Palacios, 2011). Thus, the continental species pool feeding the Azores appears to be mainly from Northwestern Europe (Schaefer, 2003), rather than the Mediterranean region, which is the main source area of Madeiran and Canarian lineages (Bramwell, 1980).

On the other hand, the majority of Azorean woody species (Ilex, Juniperus, Laurus, Morella, Picconia, Prunus, etc.) belong to what has been considered the Palaeoendemic tree-species element, distributed in Central and Southern Europe earlier in the Cenozoic and now shared with Madeira and the Canaries (Fernández-Palacios et al., 2011). However, recent phylogenetic studies by Kondraskov et al. (2015) indicate that many of these taxa colonized Macaronesia within the last $5 \mathrm{Myr}$, a timing more consistent with that of radiating taxa (Kim et al., 2008). Most of these taxa are limited to the laurel forest habitat and do not diversify within any archipelago. Nevertheless, whereas Madeira and the Canaries share a single given species in these genera, Azorean species are endemic to that archipelago, suggesting that isolation has played a role in distinguishing the Azorean flora.

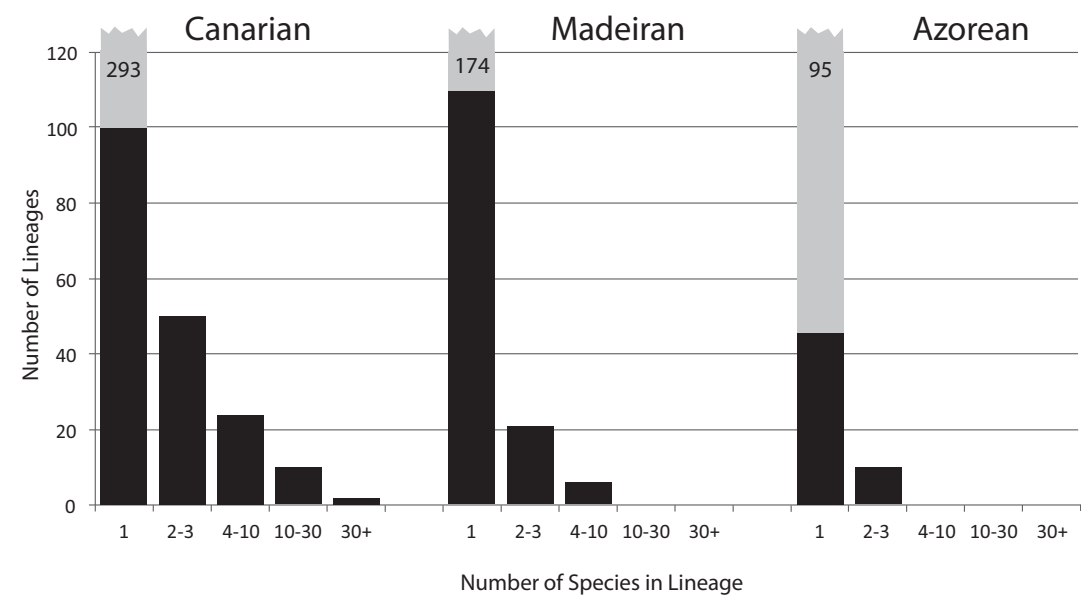

FIGURE 4 Distribution of lineage size among Macaronesian archipelagos. Numbers of single-species lineages that have differentiated from ancestral species to form an endemic species (anagenetic lineages) and lineages with multiple endemic species (diversifying lineages) are shown in black. Single-species lineages consisting of non-endemic species are shown in grey with the total number indicated near the break at the top. Numbers of endemic lineages are given in logarithmically increasing class sizes of species number 
The results of our multiple regression SAR approach clearly indicate that the Azores perfectly fit into the other two archipelagos in terms of species-area relationships when accounting for geological age of the island, geological age of the whole archipelago ("archipelago age effect"), environmental diversity and distance to the lberian Peninsula. While our overall analyses generally support the findings of Triantis, Hortal, et al. (2012), that the Azores islands are geologically too young and environmentally too homogenous to attain a high level of species richness, the distinctiveness of Azorean diversifying lineages underscores the importance of looking beyond species richness and endemicity and of closely examining the behaviour of multiple phylogenetic lineages.

\section{ORCID}

Jonathan P. Price (iD http://orcid.org/0000-0002-0084-8496 Miguel Menezes de Sequeira (iD https://orcid.org/0000-0001-9728465X

Hanno Schaefer (iD http://orcid.org/0000-0001-7231-3987 José María Fernández-Palacios iD http://orcid.org/0000-0001-97416878

\section{REFERENCES}

Acebes, J. R., León, M. C., Rodríguez Navarro, M. L., del Arco, M., García Gallo, A., Pérez de Paz, P. L., ... Wildpret, W. (2010). Pteridophyta, Spermatophyta. In M. Arechavaleta, S. Rodríguez, N. Zurita \& A. GarCía (Eds.), Lista de especies silvestres de Canarias. Hongos, plantas y animales terrestres. 2009 (pp. 119-172). Santa Cruz de Tenerife, Spain: Gobierno de Canarias.

Allan, G. J., Francisco-Ortega, J., Santos-Guerra, A., Boerner, E., \& Zimmer, E. A. (2004). Molecular phylogenetic evidence for the geographic origin and classification of Canary Island Lotus (Fabaceae: Loteae). Molecular Phylogenetics and Evolution, 32, 122-138.

Baldwin, B. G., \& Wagner, W. L. (2010). Hawaiian angiosperm radiations of North American origin. Annals of Botany, 105, 849-879. https:// doi.org/10.1093/aob/mcq052

Barber, J. C., Francisco-Ortega, J., Santos-Guerra, A., Marrero, A., \& Jansen, R. K. (2000). Evolution of endemic Sideritis (Lamiaceae) in Macaronesia: Insights from a chloroplast DNA restriction site analysis. Systematic Botany, 25, 633-647. https://doi.org/10.2307/2666725

Bates, D., Maechler, M., Bolker, B., \& Walker, S. (2014). Ime4: Linear mixed-effects models using Eigen and S4. R package version 1.1-7, http://CRAN.R-project.org/package $=$ Ime4

Böhle, U. R., Hilger, H. H., \& Martin, W. F. (1996). Island colonisation and evolution of the insular woody habit in Echium L. (Boraginaceae). Proceedings of the National Academy of Sciences of the United States of America, 93, 11740-11745. https://doi.org/10.1073/pnas.93.21. 11740

Borregaard, M. K., Amorim, I. R., Borges, P. A., Cabral, J. S., FernándezPalacios, J. M., Field, R., ... Whittaker, R. (2017). Oceanic island biogeography through the lens of the general dynamic model: Assessment and prospect. Biological Reviews, 92, 830-853. https://doi.org/ 10.1111/brv.12256

Bramwell, D. (1980). Contribución a la Biogeografía de las Islas Canarias. Botánica Macaronésica, 14, 3-34.

Burnham, K. P., \& Anderson, D. R. (2002). Model selection and multimodel inference. A practical information-theoretic approach. New York, NY: Springer.
Carine, M., \& Schaefer, H. (2010). The Azores diversity enigma: Why are there so few Azorean endemic flowering plants and why are they so widespread? Journal of Biogeography, 37, 77-89.

Carlquist, S. (1974). Island Biology. New York, NY: Columbia University Press. https://doi.org/10.5962/bhl.title.63768

Caujapé-Castells, J., García-Verdugo, C., Marrero-Rodríguez, A., Fernández-Palacios, J. M., Crawford, D. J., \& Mort, M. E. (2017). Island ontogenies, syngameons, and the origins of genetic diversity in the Canarian flora. Perspectives in Plant Evolution, Ecology and Systematics, 27, 9-22. https://doi.org/10.1016/j.ppees.2017.03.003

Cowie, R. H., \& Holland, B. S. (2006). Dispersal is fundamental to biogeography and the evolution of biodiversity on oceanic islands. Journal of Biogeography, 33, 193-198. https://doi.org/10.1111/j. 1365-2699.2005.01383.x

Curto, M., Puppo, P., Kratschmer, S., \& Meimberg, H. (2017). Genetic diversity and differentiation patterns in Micromeria from the Canary Islands are congruent with multiple colonisation dynamics and the establishment of species syngameons. BMC Evolutionary Biology, 17, 198. https://doi.org/10.1186/s12862-017-1031-y

de Nascimento, L., Willis, K. J., Fernández-Palacios, J. M., Criado, C., \& Whittaker, R. J. (2009). The long-term ecology of the lost forests of La Laguna. Journal of Biogeography, 36, 499-514. https://doi.org/10. 1111/j.1365-2699.2008.02012.x

de Nicolás, J. P., Fernández-Palacios, J. M., Ferrer, F. J., \& Nieto, E. (1989). Inter-island floristic similarities within the Macaronesian region. Vegetatio, 84, 117-125. https://doi.org/10.1007/BF00036512

del Arco, M., Pérez-de-Paz, P. L., Acebes, J. R., González-Mancebo, J. M., Reyes-Betancort, J. A., Bermejo, J. A., ... González-González, R. (2006). Bioclimatology and climatophilous vegetation of Tenerife (Canary Islands). Annales Botanici Fennici, 43, 167-192.

Domínguez-Lozano, F., Price, J., Otto, R., \& Fernández-Palacios, J. M. (2010). Using taxonomic and phylogenetic evenness to compare diversification in two island floras. Perspectives in Ecology, Evolution and Systematics, 12, 93-106. https://doi.org/10.1016/j.ppees.2009. 12.001

Fernández-Palacios, J. M. (2011). The islands of Macaronesia. In A. R. M. Serrano, P. A. V. Borges, M. Boieiro \& P. Oromí (Eds.), Terrestrial arthropods of Macaronesia. Biodiversity, ecology and evolution (pp. 1-30). Lisboa, Portugal: Sociedade Portuguesa de Entomología.

Fernández-Palacios, J. M., \& Andersson, C. (2000). Geographical determinants of the biological richness in the Macaronesian region. Acta Phytogeographica Suecica, 85, 41-50.

Fernández-Palacios, J. M., de Nascimento, L., Otto, R., Delgado, J. D., Garcia-del-Rey, E., Arévalo, J. R., \& Whittaker, R. J. (2011). A reconstruction of PaleoMacaronesia, with particular reference to the longterm biogeography of the Atlantic islands laurel forests. Journal of Biogeography, 38, 226-246. https://doi.org/10.1111/j.1365-2699. 2010.02427.x

Fernández-Palacios, J. M., \& Dias, E. (2001). Marco biogeográfico macaronésico. In J. M. Fernández-Palacios \& J. L. Martín-Esquivel (Eds.), Naturaleza de las Islas Canarias. Ecología y Conservación (pp. 45-52). Santa Cruz de Tenerife, Spain: Editorial Turquesa.

Fernández-Palacios, J. M., Negrín, Z., Fernández Lugo, S., Arévalo, J. R., \& de Nascimento, L. (in press). Terrestrial biota checklist of the Chinijo archipelago and Lobos (Canary Islands). Scientia Insularum, 1, in press.

Forjaz, V. H. (2002). Guia Geológico do Vulcão das Setes Cidades. Ponta Delgada. Observatório Vulcanológico dos Açores.

Fosberg, F. R. (1948). Derivation of the flora of the Hawaiian Islands. In E. C. Zimmerman (Ed.), Insects of Hawai'i, vol. 1 (pp. 107-119). Honolulu, HI: University of Hawai'i Press.

França, Z., Cruz, J. V., Nunes, J. C., \& Forjaz, V. H. (2005). Geologia dos Açores: uma perspectiva actual. Ponta Delgada, Portugal: Observatório Vulcanológico e Geotérmico dos Açores.

Francisco-Ortega, J., Fuertes-Aguilar, J., Kim, S. C., Santos-Guerra, A., Crawford, D. J., \& Jansen, R. K. (2002). Phylogeny of the 
Macaronesian endemic Crambe section Dendrocrambe (Brassicaceae) based on internal transcribed spacer sequences of nuclear ribosomal DNA. American Journal of Botany, 89, 1984-1990. https://doi.org/10. 3732/ajb.89.12.1984

Francisco-Ortega, J., Jansen, R. K., \& Santos-Guerra, A. (1996). Chloroplast DNA evidence of colonisation, adaptive radiation, and hybridization in the evolution of the Macaronesian flora. Proceedings of the National Academy of Sciences of the United States of America, 93, 4085-4090. https://doi.org/10.1073/pnas.93.9.4085

García-Talavera, F. (1999). Consideraciones geológicas, biogeográficas y paleoecológicas. In J. M. Fernández-Palacios, J. J. Bacallado \& J. A. Belmonte (Eds.), Ecología y cultura en Canarias (pp. 39-63). Santa Cruz de Tenerife, Spain: Museo de la Ciencia y el Cosmos, Cabildo Insular de Tenerife.

Geldmacher, J., van den Bogaard, P., Hoernle, K., \& Schmincke, H.-U. (2000). The ${ }^{40} \mathrm{Ar} /{ }^{39} \mathrm{Ar}$ age dating of the Madeiras and hotspot track (eastern North Atlantic). Geochemistry, Geophysics, Geosystems, 1, 126.

Harbaugh, D. T., \& Baldwin, B. G. (2007). Phylogeny and biogeography of the sandalwoods (Santalum, Santalaceae): Repeated dispersals throughout the Pacific. American Journal of Botany, 94, 1028-1040. https://doi.org/10.3732/ajb.94.6.1028

Heaney, L. R. (2000). Dynamic disequilibrium: A long-term, large-scale perspective on the equilibrium model of island biogeography. Global Ecology and Biogeography, 9, 59-74. https://doi.org/10.1046/j.13652699.2000.00163.x

Jardim, R., \& deMenezes Sequeira, M. (2008). List of vascular plants (Pteridophyta and Spermatophyta). In P. A. V. Borges, C. Abreu, A. M. F. Aguiar, P. Carvalho, P.R. Jardim, I. Melo, ... P. Vieira (Eds.), A list of the terrestrial fungi, flora and fauna of Madeira and Selvagens archipelagos (pp. 179-208). Funchal, Portugal: Direcção Regional do Ambiente da Madeira e Universidade dos Açores.

Kim, S. C., Francisco-Ortega, J., \& Santos-Guerra, A. (1996). A common origin for woody Sonchus and five related genera in the Macaronesian islands: Molecular evidence for extensive radiation. Proceedings of the National Academy of Sciences of the United States of America, 93, 7743-7748. https://doi.org/10.1073/pnas.93.15.7743

Kim, S.-C., McGowen, M. R., Lubinsky, P., Barber, J. C., Mort, M. E., \& Santos-Guerra, A. (2008). Timing and tempo of early and successive adaptive radiations in Macaronesia. PLoS ONE, 3(5), e2139. https://d oi.org/10.1371/journal.pone.0002139

Kisel, Y., \& Barraclough, T. G. (2010). Speciation has a spatial scale that depends on levels of gene flow. The American Naturalist, 175, 316334. https://doi.org/10.1086/650369

Kondraskov, P., Schütz, N., Schüßler, C., Menezes de Sequeira, M., Santos-Guerra, A., Caujapé-Castells, J., ... Thiv, M. (2015). Biogeography of Mediterranean hotspot biodiversity: Re-evaluating the 'Tertiary Relict' hypothesis of Macaronesian laurel forests. PLOS ONE, 10(7), e0132091. https://doi.org/10.1371/journal.pone.0132091

Kunkel, G. (1970). Flórula de la isla de Lobos (Islas Canarias). Monographiae Biologicae Canariensis, 1, 1-60.

Kunkel, G. (1971). La vegetación de La Graciosa y notas sobre Alegranza, Montaña Clara y el Roque del Infierno (Islas Canarias). Monographiae Biologicae Canariensis, 2, 1-67.

Lledó, M. D., Crespo, M. B., Fay, M. F., \& Chase, M. W. (2005). Molecular phylogenetics of Limonium and related genera (Plumbaginaceae): Biogeographical and systematic implications. American Journal of Botany, 92, 1189-1198. https://doi.org/10.3732/ajb.92.7.1189

Lomolino, M. V. (2000). A call for a new paradigm of island biogeography. Global Ecology and Biogeography, 9, 1-6. https://doi.org/10.1046/j. 1365-2699.2000.00185.x

Losos, J. B., \& Schluter, D. (2000). Analysis of an evolutionary speciesarea curve. Nature, 408, 847-850. https://doi.org/10.1038/3504 8558
MacArthur, R. H., \& Wilson, E. O. (1963). An equilibrium theory of insular zoogeography. Evolution, 17, 373-387. https://doi.org/10.1111/j. 1558-5646.1963.tb03295.x

MacArthur, R. H., \& Wilson, E. O. (1967). An equilibrium theory of island biogeography. Princeton, CA: Princeton University Press.

Marrero, A. (1991). La flora y la vegetación del Parque Natural de "Los islotes del Norte de Lanzarote y Riscos de Famara". Su situación actual. In E. Dias, J. P. Carretas \& P. Cordeiro (Eds.), Primeras Jornadas Atlânticas de Protecção do Meio Ambiente (pp. 195-214). Angra do Heroismo, Portugal: Direcção Regional do Ambiente.

McCullagh, P., \& Nelder, J. A. (2002). Generalized linear models (2nd edn). New York, NY: Chapman \& Hall.

Meimberg, H., Abele, T., Braeuchler, C., Mckay, J. K., Pérez de Paz, P. L., \& Heubl, G. (2006). Molecular evidence for adaptive radiation of Micromeria Benth. (Lamiaceae) on the Canary Islands as inferred from chloroplast and nuclear DNA sequences and ISSR fingerprint data. Molecular Phylogenetics and Evolution, 41, 566-578. https://doi.org/ 10.1016/j.ympev.2006.05.037

Mestre Barceló, A., Chazzara Bernabé, A., Pires, V., Cunha, S., Silva, Á., \& Marques, J, ... Neto, J. (2012). Climate atlas of the archipelagos of the Canary Islands, Madeira and the Azores. Air temperature and precipitation (1971-2000). Lisboa and Madrid, Spain: AEMET-IP.

Mort, M. E., Soltis, D. E., Soltis, P. S., Francisco-Ortega, J., \& SantosGuerra, A. (2002). Phylogenetics and evolution of the Macaronesian clade of Crassulaceae inferred from nuclear and chloroplast sequence data. Systematic Botany, 27, 271-288.

Otto, R., Whittaker, R. J., von Gaisberg, M., Stierstorfer, C., NaranjoCigala, A., Steinbauer, M., ... Fernández-Palacios, J. M. (2016). Transferring and implementing the general dynamic model of oceanic island biogeography at the scale of island fragments: The role of geological age and topography in plant diversification in the Canaries. Journal of Biogeography, 43, 911-922. https://doi.org/10.1111/jbi. 12684

Price, J. P. (2004). Floristic biogeography of the Hawaiian Islands: Influences of area, environment, and paleogeography. Journal of Biogeography, 31, 487-500. https://doi.org/10.1046/j.0305-0270.2003.00 990.x

Price, J. P., \& Wagner, W. (2011). A phylogenetic basis for species-area relationships among three pacific island floras. American Journal of Botany, 98, 449-459. https://doi.org/10.3732/ajb.1000388

Quinn, C. L., Cravn, D. M., Heslewood, M. M., Brown, E. A., \& Gadek, P. A. (2003). A molecular estimate of the phylogeny of Styphelieae (Ericaeae). Australian Systematic Botany, 18, 439-454.

Quinn, G. P., \& Keough, M. J. (2002). Experimental design and data analysis for biologists. Cambridge, UK: Cambridge University Press.

R Development Core Team (2017). R: A language and environment for statistical computing. Retrieved from https://www.R-project.org/

Ramalho, R. S., Helffrich, G., Madeira, J., Cosca, M., Thomas, C., Quartau, R., ... Ávila, S. P. (2017). Emergence and evolution of Santa Maria Island (Azores) - The conundrum of uplifted islands revisited. Geological Society of America Bulletin, 129, 372-391. https://doi.org/10. 1130/B31538.1

Rando, J. C., Cabrera, V. M., Larruga, J. M., Hernández, M., González, A. M., Pinto, F., \& Bandelt, H. J. (1999). Phylogeographic patterns of mtDNA reflecting the colonisation of the Canary Islands. Annals of Human Genetics, 63, 413-428. https://doi.org/10.1046/j.1469-1809. 1999.6350413.x

Reyes-Betancort, A., Santos-Guerra, A., Guma, R., Humphries, C. J., \& Carine, M. (2008). Diversity, rarity and the evolution and conservation of the Canary Islands endemic flora. Anales del Jardín Botánico de Madrid, 65, 25-45.

Rijsdijk, K. F., Hengl, T., Norder, S., Otto, R., Emerson, B. C., Ávila, S. P., ... Fernández-Palacios, J. M. (2014). Quantifying surface area changes of volcanic islands driven by Pleistocene sea level cycles: 
Biogeographic implications for Macaronesian archipelagos, Atlantic Ocean. Journal of Biogeography, 41, 1227-1439.

Rosenzweig, M. (1995). Species diversity in space in time. Cambridge, UK: Cambridge University Press. https://doi.org/10.1017/CBO9780511623387

Santos, A. M. C., Whittaker, R. J., Triantis, K. A., Borges, P. A. V., Jones, O. R., Quicke, D. L., \& Hortal, J. (2010). Are species-area relationships from entire archipelagos congruent with those of their constituent islands? Global Ecology and Biogeography, 19, 527-540.

Schaefer, H. (2003). Chorology and diversity of the Azorean flora. Dissertationes Botanicae, 374, 1-130.

Schaefer, H., Moura, M., Belo Maciel, G., Silva, L., Rumsey, F. J., \& Carine, M. A. (2011). The Linnean shortfall in oceanic island biogeography: $A$ case study in the Azores. Journal of Biogeography, 38, 1345-1355. https://doi.org/10.1111/j.1365-2699.2011.02494.x

Sibrant, A. L. R., Hildenbrand, A., Marques, F. O., Weiss, B., Boulesteix T., Hübscher, C., ... Catalão, J. C. (2015). Morpho-structural evolution of a volcanic island developed inside an active oceanic rift: S. Miguel Island (Terceira Rift, Azores). Journal of Volcanology and Geothermal Research, 301, 90-106. https://doi.org/10.1016/j.jvolgeores.2015.04. 011

Silva, L., Moura, M., Schaefer, H., Rumsey, F., \& Dias, E. F. (2010). List of vascular plants (Tracheobionta). In P. A. V. Borges, A. Costa, R. Cunha, R. Gabriel, V. Gonçalves, A. F. Martins, ... V. Vieira (Eds.), A list of the terrestrial and marine biota from the Azores (pp. 117-146). Cascais, Portugal: Princípia.

Stuessy, T. F., Jakubowsky, G., Salguero Gómez, R., Pfosser, M., Schlüter, P. M., Fer, T., ... Kato, H. (2006). Anagenetic evolution in island plants. Journal of Biogeography, 33, 1259-1265. https://doi.org/10. 1111/j.1365-2699.2006.01504.x

Susanna, A., Garnatje, T., \& García-Jacas, N. (1999). Molecular phylogeny of Cheirolophus (Asteraceae: Cardueae-Centaureinae) based on ITS sequences of nuclear ribosomal DNA. Plant Systematics and Evolution, 215, 147-160. https://doi.org/10.1007/BF00985736

Swenson, U., \& Manns, U. (2003). Phylogeny of Pericallis (Asteraceae): A total evidence approach reappraising the double origin of woodiness. Taxon, 52, 533-546. https://doi.org/10.2307/3647452

Takayama, K., Crawford, D. J., López-Sepúlveda, P., Greimler, J., \& Stuessy, T. F. (2018). Factors driving adaptive radiation in plants of oceanic islands: A case study from the Juan Fernández Archipelago. Journal of Plant Research, 131, 469-485. https://doi.org/10.1007/ s10265-018-1023-z

Triantis, K. A., Borges, P. A. V., Ladle, R. J., Hortal, J., Cardoso, P., Gaspar, C., ... Melo, C. (2010). Extinction debt on oceanic islands. Ecography, 33, 285-294.

Triantis, K. A., Economo, E. P., Guilhaumon, F., \& Ricklefs, R. E. (2015). Diversity regulation at macro-scales: Species richness on oceanic archipelagos. Global Ecology and Biogeography, 24, 594-605. https://d oi.org/10.1111/geb.12301

Triantis, K. A., Guilhaumon, F., \& Whittaker, R. J. (2012). The island species-area relationship: Biology and statistics. Journal of Biogeography, 39, 215-231. https://doi.org/10.1111/j.1365-2699.2011.02652.x
Triantis, K. A., Hortal, J., Amorim, I., Cardoso, P., Santos, A. M. C., Gabriel, R., \& Borges, P. A. V. (2012). The Azorean diversity is not enigmatic: Resolving the Azorean knot. A response to Carine \& Schaefer (2010). Journal of Biogeography, 39, 1179-1184. https://doi.org/10.1111/j. 1365-2699.2011.02623.x

Triantis, K. A., Whittaker, R. J., Fernández-Palacios, J. M., \& Geist, D. J. (2016). Oceanic archipelagos: A perspective on the geodynamics and biogeography of the World's smallest biotic provinces. Frontiers of Biogeography, 8, fb_29605.

Vieira, A. (2001). História da Madeira. Funchal, Portugal: Secretaria Regional da Educação. Governo da Madeira.

Whittaker, R. J., Ladle, R. J., Araújo, M. B., Fernández-Palacios, J. M., Delgado, J. D., \& Arévalo, J. R. (2007). The island immaturity - Speciation pulse model of island evolution: An alternative to the "diversity begets diversity" model. Ecography, 30, 321-327. https://doi.org/10. 1111/j.0906-7590.2007.04761.x

Whittaker, R. J., Triantis, K. A., \& Ladle, R. J. (2008). A general dynamic theory of oceanic island biogeography. Journal of Biogeography, 35, 977-994. https://doi.org/10.1111/j.1365-2699.2008.01892.x

Yi, T., Miller, A. J., \& Wen, J. (2004). Phylogenetic and biogeographic diversification of Rhus (Anacardiaceae) in the Northern hemisphere. Molecular Phylogenetics and Evolution, 33, 861-879. https://doi.org/ 10.1016/j.ympev.2004.07.006

\section{BIOSKETCH}

Jonathan Price is Associate Professor and chair of the department of Geography and Environmental Studies at the University of Hawaii at Hilo. His research attempts to understand regional species pools, particularly those of island floras, by examining phyletic evolution in the light of climatic and geological history.

\section{SUPPORTING INFORMATION}

Additional supporting information may be found online in the Supporting Information section at the end of the article.

How to cite this article: Price JP, Otto R, de Sequeira MM, et al. Colonization and diversification shape species-area relationships in three Macaronesian archipelagos. J Biogeogr. 2018;00:1-13. https://doi.org/10.1111/jbi.13396 